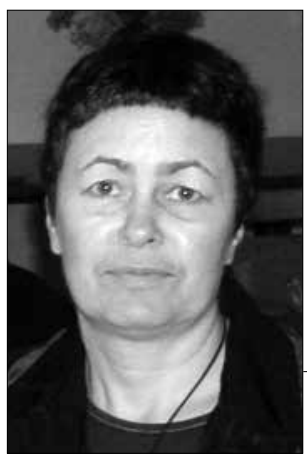

https://doi.org/10.24101/logos.2017.50

IRMA ŠIDIŠKIENĖ

Lietuvos istorijos institutas

Lithuanian Institute of History

\title{
NEFORMALIŲ KAIMO IR MIESTO DARBO BENDRIJŲ SĄSAJOS SOCIALINIŲ SANTYKIŲ ASPEKTU
}

\author{
The Relationship Between Informal Rural \\ and Urban Communities in the Aspect \\ of Social Relations
}

\begin{abstract}
SUMMARY
The article deals with the informal social networks of the labor community. In order to reveal the importance of informal communication, the article compares a rural (as a source of tradition) and a current city employment community. The comparison showed that in the context of informal networks of the traditional communities and of urban collaborators, social relationships formed reciprocity (help), mutual trust, the differences between these communities, local dimension (as economic - rural community and culture of the organization - the city), and the fact that in the rural community, unstressed time (duration, frequency), is assumed as long-term and steady, while in urban communities there is an emic point of view. The gender aspect aspect was not highlighted.
\end{abstract}

\section{SANTRAUKA}

Straipsnyje nagrinėjami darbo bendrijų neformalieji tinklai socialinių santykių aspektu. Siekdami atskleisti neformaliųjų ryšių reikšmę darbo kolektyve, socialinių santykių aspektu iš laiko perspektyvos lyginsime kaimo (kaip tradicijos šaltinio) ir dabartines miesto darbo bendrijas. Palyginimas parodè, kad darbo kontekste neformalių tinklų tradicinès bendruomenės ir miesto bendradarbių socialinius santykius formavo abipusiškumas (pagalba), tarpusavio pasitikèjimas. Skiriasi šių bendruomenių vietos aspektas (kaip ekonominis - kaimo bendrijoje ir organizacijos kultūros - miesto) ir tai, kad kaimo bendrijoje neakcentuotas laikas (trukmė, dažnumas), kuris numanomas kaip ilgalaikis, pastovus, o miesto bendrijoje emic požiūriu nebuvo išskirtas lyties aspektas, kuris, manyčiau, taip pat nutylimas kaip savaime suprantamas. 


\section{IVADAS}

Neformalių, savaiminių tinklų ištakos ir jų vertè, t. y. nauda ekonominiams rezultatams ar socialinei kultūrinei organizacijos, bendruomenès aplinkai, domino įvairių sričių tyrëjus: antropologus, ekonomistus, sociologus, politikos mokslų atstovus. Gausioje formalių ir neformalių tinklų istoriografijoje anglu kalba nemažai dèmesio skirta socialinių tinklų, kurie yra svarbūs tiriant organizacini tapatumą ir organizacinę internalizacija, analizei ${ }^{1}$, neformalių tinklų susidarymui, tvarumui tokių reikšmingų aspektų kaip pasitikèjimas, kultūros normos, abipusiškumo, bausmès ${ }^{2}$ nagrinejjimui ir kita. Mokslininkai kalba apie socialinių tinklų galią pakeisti oficialiuosius ryšius. $\mathrm{Ne}$ formalieji ryšiai, paremti bendru tikslu ir abipusiu pasitikejjimu, padeda darbo grupei funkcionuoti ir be oficialiujuc ryšių ${ }^{3}$. Be to, ir formaliaisiais ryšiais siejami socialiniai santykiai yra stiprinami neformaliaisiais ryšiais. Savaiminiais, netarpiškais, t. y. neformaliais, bendradarbių tarpusavio ryšiais sukuriama abipusiškai naudinga socialinè vertė (abiem pusėms galinti pasireikšti ne vienu metu). Taigi, glaustai apibrèždami skirtumus tarp formaliu ir neformalių tinklų, galèsime geriau suvokti neformalių, savaiminių tinklų reikšmę.

Socialini tinklą sociologai, ekonomistai, antropologai ir kiti mokslininkai apibrèžia labai ivvairiai, bet bendriausia prasme tai yra ryšys tarp vieno tikslo veikèju, kurie sąveikauja jame formaliai ir neformaliai, keičiasi vertingomis žiniomis, resursais. Svarbiausias socialiniu tinklų tikslas - sukurti tarp keleto veikèjų bendrą vertę, kuri jiems gali būti nau- dinga. Socialiniai tinklai suvokiami kaip ištekliai asmenims, galintys palengvinti kolektyvinius veiksmus bei paremti abipusiškumu, pasitikejjimu, atskaitingais ryšiais (accountable ties) ${ }^{4}$ ir normomis, dar vadinami socialiniu kapitalu ${ }^{5}$. Skirtumai tarp formalių ir neformalių tinklų, manyčiau, aiškiau išskiriami struktūrinejje plotmèje. Formalūs tinklai ribojami taisyklèmis ir kontraktais stengiantis kontroliuoti ir koordinuoti informaciją ir tinklo struktūrą. Formalus tinklas tipiškai yra vertikalus, jam būdinga standi vadovavimo grandine ir remiasi lyderiais, kurie sugeba sąveiką valdyti. Neformalūs tinklai yra ne tokie standūs, ne visuomet paremti kontraktais, jie leidžia veikëjams judèti bet kuria kryptimi, apeiti valdžią ir yra labiau socialiai struktūruoti ${ }^{6}$. Jie paremti dalinimusi informacija, žiniomis ar kitkuo bei apibūdinami asinchronišku abipusiškumu. Pagrindinè neformalių tinklų problema yra atsitiktinumu paremta struktūra. Tyrime svarbu išskirti kriterijus, pagal kuriuos vertinami tinklai. Vienas tokių kriterijų - tinklo struktūros tamprumas, kuris tiek formaliu (arba vertikalių), tiek neformalių (horizontalių) tinklų atvejais matuojamas dažnumu, tankumu ir laiko trukme.

Straipsnyje siekiama atskleisti neformalių tinklų reikšmę darbo kolektyve. Lygindama XIX a. pab.-XX a. pirmosios pusès kaimo bendruomenès talkose susiburiančių bendriju ir XX a. antrosiosXXI a. pr. miesto bendradarbiu socialinių santykių bruožus, mėginsiu atskleisti jas siejančius ir skiriančius aspektus. Tiek pirmosios, tiek antrosios darbo bendrijos skirtingos, tačiau jų neforma- 
lieji tinklai, manyčiau, panašūs, nes pagrịsti savanoriškumo principu, yra mobilūs ir pan. Remdamasi kaimo bendruomenès talkų tyrimais, atliktais Lietuvos etnologu, išryškinsiu jose kuriamu socialinių santykiu aspektus. Miesto bendradarbių socialinius santykius, kuriamus neformaliuose susiejjimuose, atskleisiu remdamasi savo surinktais etnografinio tyrimo duomenimis ${ }^{7}$, kai ịvairaus amžiaus vilniečiai apibūdino, kaip jie suvokia bendradarbių bendriją. Palyginimas tarp etic ir emic požiūrių rizikingas, nes etic atveju akcentuojami realijos išraiškos aspektai (šiuo atveju talkų dalyvių elgsena), o emic požiūriu daugiau mentalinè, pateikèjų modeliuota suvokiama realija, tačiau, mano galva, analizuojant bendrijos socialinius santykius, elgsenos normas, taip pat išryškèja ar yra nuspejjamas tiriamujju veikèju savos bendrijos suvokimas.

\section{TRADICINIŲ TALKŲ DARBO BENDRIJOS NEFORMALIEJI RYŠIAI}

Darbo kolektyvo socialiniai santykiai tradicinëje kaimo bendruomenëje geriausiai išryškèja darbo papročiuose ir ypač talkų tyrimuose Iš svarbesnių talkų tyrinètojų galima paminèti keletą autorių. Darbo šventes ir papročius, samdiniu kasdienybę tyrę autoriai palietė ir tal$\mathrm{kas}^{8}$. Daug talkų fenomeno tyrimų atliko Jonas Mardosa. Jis gvildeno talkų ekonominius, apeiginius aspektus, išryškino čia atsiskleidžiančius erotinius, krikščioniškus motyvus. Tyrimuose paminèti talkų dalyvių darbų pasiskirstymas, vedančiojo ir šeimininkès(-ko) vaidmuo (kaip pradedama ir baigiama talka), bendravimas, kontaktai pertraukų ir pabaigtuvių metu (vaišès ir linksmybès) ${ }^{9}$. Žilvytis Šaknys tyre jaunimo pasilinksminimų (kalendorinių švenčių ir patalkių vakarèlių) socialinès reikšmès arealinius skirtumus ${ }^{10}$. Auksuolè Čepaitienè, tyrusi verpimo kultūrą ir socialinius aspektus, aptarè ir bendravimą verpimo vakaronių metu ${ }^{11}$. Šių darbų ižvalgos padèjo suformuluoti talkose susiburiančio, paprastai savanoriškai, darbo kolektyvo socialinius santykius.
Kaime formalius darbo kolektyvus sudare atskiri ūkio vienetai, o priklausomai nuo istorinio laikotarpio, tai galèjo būti dvaras, kaimas ar šeima su samdiniais ir pan. Talkų metu suburiama ar susiburia laikina darbo bendrija, skirta greičiau, racionaliau atlikti darbą ar pagelbèti nelaimejje. Laikinos neformalios darbo bendrijos kaimo bendruomenèje susiburdavo priklausomai ir nuo darbo pobūdžio pagal amžiaus grupes (pvz., jaunimo), ar kaimynystę, giminystę, lytį. Vienos talkos buvo merginu, moteru (linų rovimo, brukimo, verpimo, pūkų plěšymo, skalbimo, rugių pjovimo pjautuvais - iki Pirmojo pasaulinio karo, bulviakasio), kitos vyrų (linų šukavimo ${ }^{12}$, miško, molio vežimo, statybų). Mišriose talkose pasidalindavo darbais, pvz., mèšlą mèžè: iškraudavo vyrai, kratè moterys, vežiojo ì laukus paaugliai. Linus laužè vyrai, mynè moterys, javus pjovè dalgiais vyrai, pėdus rišo moterys. Svarbus talkų bendrijos aspektas yra ir vieta. Anot Ž. Šaknio, dèl skirtingų ekonominių vienetu - kaimo ir vienkiemio - susiklostè bendruomeniniai ar individua- 
listiniai santykiai: Rytų areale (Aukštaitija ir Dzūkija) talkas suburdavo iš kaimo bendruomenės atstovų, Vakarų (Mažoji Lietuva, Žemaitija ir Suvalkija, kai kurios Šiaurès Aukštaitijos vietovès) - iš kaimynų, giminaičių tarpo ${ }^{13}$.

Kaimiečiai kvietėsi į talkas patikimus kaimo bendruomenès narius, kuriuos pažinojo kaip tvarkingus, atsakingus, darbščius, stiprius ar išmanančius darba, taip pat kviesdavo giminaičius, skolininkus (dvarai), telkè padienius, kartais samdè. Dalyvavimas atbūtinèse ${ }^{14}$ talkose pagrìstas abipusiškumo principu (padeda vienas kitam). Didesnès talkos baigdavosi vaišėmis ir vakarone su šokiais. Atsitikus nelaimei, gaisrui, susirgus ar netekus šeimos galvos, sueidavo žmonès padèti ir nekviesti, šiems nebuvo ruošiamos vaišès.

Talkų, darbo švenčių tyrimuose atskiro dėmesio sulaukẻ vaišių fenomenas, vakaronių papročiai. Darbo šventès ar vaišès (work feast) tyrëjų (remiuosi Dietler, M., \& Herbich tyrimais ${ }^{15}$ ) laikomos ne tik atlyginimu (būdingu ikimonetarinei visuomenei), bet ir vienu iš būduc mobilizuoti darbui (talkai) daugiau žmonių, kartu turi politinès ekonomikos reikšmę - padeda sukurti ekonomini ir simbolinį kapitalą. Tai, viena vertus, socialinis įvykis visiems, kita vertus, stiprina šeimininko gerovę ekonomiškai, o bendros vaišès padidina šeimininko reputaciją (jis igyja simbolini kapitalą) ${ }^{16}$. Lietuvių tyrèjai daugiau dèmesio skyrè vaišių maistui, ritualiniam užgėrimui, vaišinimui, apeigoms ir papročiams ${ }^{17}$, tačiau gausių vaišių tiekimas per vestuves $X X$ a. 7-8 dešimtmečiais buvo sutapatintas su „nesveikomis miesčioniško pragmatizmo persunktomis orientacijomis $\mathfrak{i}$ "prestiziškumą"18. Vadinasi, čia taip pat galime izžvelgti simbolinio kapitalo kaupimo aspektų. Iprasta buvo vaišes suvokti kaip svarbų atlygio už darbą būdą. Talkose, kur vaišès buvo nenumatytos, t. y. atbūtinèse talkose, samdiniai (kai vienas ūkininkas siunčia į talką kitam ūkininkui savo samdinį) iš šeimininko išprašydavo vaišiuc (degtinès buteli ar pan.), kartais šokius. Tačiau talkos jaunimui svarbios ne tiek dèl atlygio (ar vaišių), kaip pažymi talkų tyrëjai ${ }^{19}$, eiti i dideles talkas jaunimą skatino ir galimybè sueiti draugèn (t. y. pabendrauti, susipažinti, pažinti vienas kitą kasdienejje aplinkoje), dalyvauti šokiuose. Pažymètina, jog Lietuvoje ne visur po talkų buvo iprasta rengti šokius. Šaknio tyrimai parodè, jog pasilinksminimų intensyvumas, darbo ir poilsio santykis Lietuvoje skyrèsi: Rytų areale darbas ir poilsis buvo griežtai atskirtas, o Vakarų - atvirkščiai, darbas tapo švente ${ }^{20}$.

Taigi, kaip rodo talkų tyrimai Lietuvoje, socialiniai santykiai talkose klostèsi priklausomai nuo dalyvių lyties, amžiaus, giminystès, draugystès ir nuo vietos arba teritorinio artumo (kaimas, vienkiemis), kur išskiriami vieši ir uždari susibūrimai. Šie neformalieji tinklai sukuria bendrą vertę, kuri naudinga talkos dalyviams. Tokią vertę sudaro: a) supratingumas, atjauta - pagalba nelaimejje; b) abipusė pagalba (atbūtinès talkos) ar pareiga (skola); c) vaišès (didžiosios talkos) ar pasilinksminimas (Vakaru Lietuvos areale, kitur - bendravimas su kitais ne šeimoje, šeimynoje) ypač aktualu jaunimui (kuo daugiau žmonių - tuo patraukliau). 


\section{MIESTO BENDRADARBIŲ BENDRIJOS „KLIJAI“ EMIC POŽIŪRIU}

Modernioje organizacijoje puoselëjamos praktikos, kurios padètu (oficialiai, iš viršaus) sukurti darbovietès bendrija, t. y. kultūra, aplinka, atmosfera, kurioje darbuotojai puikiai jaustųsi, gerai dirbtu, atsiduotų organizacijai. Lietuvoje tokio pobūdžio bendrijų darbovietėse esama, bet dažniau galima aptikti savaime, neformaliai susiburiančių bendrijų. Nagrinėdama lauko tyrimų Vilniuje duomenis, atskleisiu emic požiūrị, kokie bruožai rodo, yra ar ne bendrija, kurią sieja neformalūs tinklai, miesto darbo kolektyve.

Apklaustų vilniečių darbo kolektyvai, priklausomai nuo darbo specifikos, buvo ivairūs: sudarẻ vieną grupę pagal lytị ar amžiu, rečiau pagal etnini aspektą ar mišrūs kolektyvai. Vieni kolektyvai buvo dideli, kiti maži, susikoncentravę vienoje vietoje ar išskaidyti po įvairias miesto, rajono ar respublikos (kitų šalių) vietas. Skirtingos patirtys ir keičiant darbovietes. Pažymètina, kad tik 23 proc. apklaustuju patys keitè darbą dèl geresniu sąlygu, kiti, jei keitè, tai dẻl tam tikru pasikeitusiu asmeninio gyvenimo aplinkybių, vyravo respondentų (ypač vyresniujjų) pastovumas darbovietės atžvilgiu. Visa tai turejo ittakos ir apklaustų vilniečiu patirčiai, kuria remdamiesi jie išsakè savo nuomonę apie bendradarbių bendriją ar kolektyvą. Dauguma apklaustu vilniečiu pabrèžè, jog bendrija yra kolektyve, pasižyminčiame draugiškumu: "Geras kolektyvas, supratimas, žmogiškumas, šiltas bendravimas" (mot., gim. 1929). Svarbiausia, dauguma tikèjo ar patyrè, kad prireikus, t. y. ištikus nelaimei, šie bendradarbiai padès, - tai pabrèžè ne vienas respondentas: „Draugiški, nuoširdūs žmonès, padedantys nelaimèje, su kuriais gera dirbti“" (mot., gim. 1968). Nors bendradarbių bendrija prilyginama darniam, geram kolektyvui, kartais šeimai ar draugams, tačiau dažnai pabrèžiami tik darbo santykiai, sutelkto darbo reikšmè, "kada vienas už visus, visi už vieną" (mot., gim. 1952) arba "visi kumštyje" (vyr., gim. 1973). Svarbu, kad bendradarbiai būtų vienminčiai, vyrautu gera komandinè dvasia, tai bendradarbiai, su kuriais galima pasikonsultuoti, spręsti problemas, nes visi reikalingi vienas kitam dèl bendro tikslo.

Tad aptartoji didžioji apklaustujų vilniečių dalis akcentuoja pasitikèjimą tarp kolektyvo nariu, kur, sakyčiau, vyrauja išgryninti darbiniai ryšiai. Žinoma, pasitikèjimą lydi draugiškumas, nuoširdumas, supratingumas, pagalba, netarpiškas bendravimas, t. y. akcentuota santykiu kokybè. Net nepatyrę gero kolektyvo $^{21}$ respondentai vylèsi, kad turètú būti netarpiški santykiai, pamažu susiklostyti tradicijos tokiame kolektyve, vienas kitam turètu „patarti, padèti, bendro darbo rezultatu siekti, nuoširdžiai palaikyti, bendrauti draugiškai, kad kartu džiaugtumeisi gyvenimu, o ne būtu tik kad atidirbi ir viskas" (vyr., gim. 1986).

Trečdalis respondentu manė, kad bendrija - dar daugiau nei darbo kolektyvas, kai santykiai palaikomi ne tik darbe, bet ir už darbo(vietės) ribu, kai sieja bendri interesai, pomėgiai. Jiems kolektyvas daugiau nei darbo rezultatų sieki- 
mas, todèl svarbu asmeninis supratingumas, pasitikejjimas, palaikymas.

Yra manančiu, jog kolektyve svarbiau bendra darbinè atmosfera, kai netrukdoma atlikti užduočių, o i bendrijas „,̌monés susiburia pagal amžiu, interesus" (mot., gim. 1969). Kartais respondentams buvo sunku apibrèžti, kaip jie suvokia bendrija, - pagalvoję nusprendè, kad „panašu i profsajungq" (mot., gim. 1954). Tiesa, iš keleto vilniečių teko išgirsti, jog darbe nèra tokio dalyko kaip „bendrijos“ ir nežino, ką tai galètų reikšti.

Kalbant apie bendriją su respondentais kaip labai svarbus dèmuo iškilo laiko dimensija: praleisto laiko kartu trukmè, istorinis laikotarpis, žmogaus amžius (arba kartos). Respondentai akcentavo, kad didelę savo gyvenimo dali praleidžia dirbdami, todèl „bendrauji, daliniesi džiaugsmais ir vargais; sieja tave visa gyvenima nuo - iki, kur dirbi" (mot., gim. 1957). Tai ypač akcentavo jaunesnieji respondentai, kurių manymu, bendrijai atsirasti reikšmès turi laikas (trukmè), praleistas kartu darbe. Kita laiko dimensija - istorinis laikotarpis ir skirtingos amžiaus grupės, kartos. Vyresni respondentai galejjo palyginti savo jaunystëje buvusius santykius darbo kolektyve ir dabar. Jiems sovietmetis - tai jaunystès laikas, ir visa atrode kitaip, tuomet visi buvo „panašaus amžiaus. Todèl pavyko susikalbèt" (mot., gim. 1942). Kiti respondentai prisiminè, jog sovietmečiu kolektyve buvo ir jaunesniu, ir vyresniu, "bendravimui tai netrukdë" (mot, gim. 1957), visi, nepaisant amžiaus skirtumų, "maloniai pabendraudavom kai būdavo laisva - susédam, kavos išgeriam" (mot., gim. 1968).
Žinoma, socialinių kultūrinių santykių pokyčius kolektyve po sovietmečio ar pasikeitus kartoms pabrèžè ne vienas respondentas. Iš pasisakymų galima numanyti, kokiame kolektyve teko dirbti respondentui, - nuo to priklause ir vertinimas. Antai vyresnieji, prisiminę sovietmeti, jaunystès metais dirbę dideliame kolektyve, kur nemažai buvo jaunimo, intensyviai palaikè su bendradarbiais ryšius ir po darbo îvairiuose sporto renginiuose, iškylose ir pan., tačiau „Paskui viskas sumaterialejo, pasikeitè, draskymaisi, privatizacijos - visa tai kolektyvui atsiliepe. Ir jau kartos keitési. Su mano išéjimu jau daug nauju atejjo" (mot., gim. 1957), - pasakojo respondentè. Panašiai ir kiti, dirbę mišriame kartų požiūriu kolektyve sovietmečiu jautė nuoširdžią vyresniųju globą: ",anksčiau [sovietmečiu], tai kolektyvas buvo..., o dabar ne - kiekvienas sau" (mot., gim. 1958).

Jaunesni respondentai taip pat pažymi, jog ir šiuolaikiniai kolektyvai skirtingi. Antai, dideliame - kiekvienas sau: „Vyresnieji atskirai, jie turi savo požiūrius, savo skoni - nèra ka ir kalbèt. Ateini naujas, jie ten su tavimi nei pažindinasi, nei ka, neisi ten pažindintis. Kolega ir tiek, ka ten su juo - nieko. Tai neišvengiama, jei jie dirba kartu jau 10 metu, turi apie ka pasikalbèti, ir dažniausiai kalba apie darbą. Kiek galima vien apie darba!!", o štai kitame darbe, kur nedidelis, jaunas "kolektyvas yra pats geriausias, koki teko turèti, vadové taip pat" (mot., gim. 1985). Vadinasi, svarbūs kolektyvą telkiantys neformalūs ryšiai. Respondentų pastebėtas ir toks momentas, kad ne tik bendri pomėgiai suartina žmones, bet ir atvirkščiai: „jei geras ko- 
lektyvas, vis vien tada išauga i bendrus pomégius, poilsí, laisvalaikï" (vyr., gim. 1973).

Kai kurie respondentai, kalbejję apie tai, kaip kolektyve modeliuojami socialiniai santykiai, pabrěžè vietos dimensija, būtent, kokie žmonès toje vietoje, darbovietejje, sudaro kolektyva, „kiekvienoje vietoje kitokie santykiai" (mot., gim. 1939). Nors respondentu akcentuota vieta, ji realiai atitinka organizacijos kultūrą (tiek formaliają, tiek neformaliają). Kaip parodė Stevenson (1996), organizacijos neformalūs tinklai atlieka pagrindinių informacijos skleidejų vaidmeni, prižiūri, reguliuoja ir perduoda organizacinę kultū$\mathrm{rą}^{22}$. Respondentai atkreipè dèmesí, kad socialiniai santykiai ne mažiau priklauso ir nuo konkrečioje darbovietėje dirbančiu žmonių charakteriu ypatybių: „Nuo vieno kitam persiduoda... Sakyčiau, būna trys charakteriai: vieni nori, kad juos visi matytu, kiti - tokie daugiau - dirba mažiau, kalba; treti - pasyvesni gal" (mot., gim. 1939). Kita respondentė manè, jog neformalių santykių trukdis yra karjeristų tipo žmo- nès, kurie kolektyve laikosi tam tikro atstumo priklausomai nuo einamu pareigų: „kolektyvas susiskirstęs: sédi trise komisijoj, tai jos skaitosi mazgiukai, parašus deda, gauna algos biski daugiau, ir save pakèle virš, nu, supranti, kiekvienas ten vaidina. Santykiai yra tokie" (mot., gim. 1957). Apibendrindami emic požiūri, galime teigti, jog bendradarbiu bendrijos sąvoka apima visų pirma gerą komandinę veiklą vykdančiu žmonių grupę, kartu ir perauganti i draugiškumą glaudesni dirbančiujų bendravimą už darbovietės ribų. Kai socialiniai tinklai darbovietėje yra tankūs, dažni ir ilgalaikiai, susiformuoja bendradarbiu bendrijos (palaikomos neformaliais tinklais), kurias respondentai prilygina šeimai, draugams. Svarbus elementas kuriant bendrija yra ir vieta, tiksliau -organizacijos kultūra, kur dirbančiujų asmeniniai charakteriai, pomégiai, tikslai atsiskleidžia arba yra nutylimi, (tikètina, priklausomai nuo susiklosčiusios / suformuotos formaliosios kultūros).

\section{IŠVADOS}

Palyginus talku tradicinejje bendruomenejje ir miesto bendradarbiu (emic požiūriu) bendrijų reikšmes, pastebèta, kad neformaliu tinklų tradicinëje bendruomenëje darbo kontekste socialinius santykius formavo abipusiškumas (pagalba), vieta kaip ūkio vienetas ir grupès pagal amžių, lytị. Galima pažymèti ir atlygi (vaišes) kaip vieną iš akstinų dalyvauti talkose. Miesto darbo kolektyve neformaliu bendrijų formavimui iztakos turi laikas (trukmè, laikotarpis, dažnumas), tarpusavio pasitikejjimas, pagalba, vieta kaip organizacijos kultūra ir, rečiau, - amžiaus grupès (kartos). Tad skiriasi vietos aspektas (kaip ekonominis ar organizacijos kultūros) ir tai, kad kaimo bendrijoje neakcentuotas laikas (trukmè, dažnumas), kuris numanomas kaip ilgalaikis, pastovus, o miesto bendrijoje, emic požiūriu, nebuvo išskirtas lyties aspektas, kuris, manyčiau, taip pat nutylimas kaip savaime suprantamas. Taip pat apibūdinant bendradarbiu bendriją neakcentuotas vaišiu (užstalès) akstinas, bet apie ji buvo užsiminta. 


\section{Literatūra ir nuorodos}

${ }^{1}$ Kathy J. Kuipers, Formal and Informal Network Coupling and its Relationship to Workplace Attachment. Sociology Faculty Publications, 2009, Paper 1. <http://scholarworks.umt.edu/sociology_pubs/1> [žr. 201607 07]

2 Ethan Bueno de Mesquita and Matthew Stephenson, Legal Institutions and Informal Networks. Journal of Theoretical Politics18(1), 2006, p. 40-67. $<$ http://jtp.sagepub.com> [žr. 201607 07]

${ }^{3}$ Ingrid H. Garmann Johnsen, Formal Project Organization and Informal Social Networks: Regional Advantages in the Emergent Animation Industry in Oslo, Norway. European Planning Studies7, Vol. 19, No. 2011.

4 Kimberly Lochner, Ichiro Kawachi, Bruce P. Kennedy, Social capital: a guide to its measurement. Health \& Place 5, 1999, p. 260.

${ }^{5}$ Michael Woolcock, The Place of Social Capital in Understanding Social and Economic Outcomes", 2000, p. 9. <http://www.oecd.org/innovation/research/1824913.pdf> [žr. 201607 01]

6 The differences between formal and informal organization, b. m., <http://www.sociologyguide.com/ organization-and-individual/differences.php> [žr. 201607 07]

${ }^{7}$ Pagal savo sudarytą klausimyną 2013-2015 m. atlikau lauko tyrimus (33 aprašai), o $2013 \mathrm{~m}$. prie tyrimo buvo prisidèję Lietuvos edukologinio un-to (LEU) Istorijos fakulteto studentai Marius Varvuolis ir Haris Simas Petrauskas (apklausta 20 vilniečių).

8 Vitalis Morkūnas, Nuo tamsos ligi tamsos (Žemès ūkio darbininku buitis Lietuvoje 1919-1940). Vilnius: Mokslas, 1977.

Angelè Vyšniauskaitè, Gẻrimas lietuvių liaudies ritualuose ir kova su girtavimu. Ritualas, Blaivybè, kultūra. A. Gaižutis ats. red, sud. Vilnius: Mintis, 1989, p. 95-122.

Pranė Dundulienè, Lietuviu šventés: tradicijos, papročiai, apeigos. Vilnius, 1991.

9 Jonas Mardosa, Valstiečiu talkos Lietuvoje: XIX a. pabaigoje $-X X$ a. pirmoje pusèje. Liaudies kultūra 5, 1997.

Jonas Mardosa, Vaiguviškių talkos XX am- žiaus pirmojoje pusėje. Elektroninio serialinio leidinio "Lietuvos lokaliniai tyrimai“, ISSN 2029-0799 visatekstëje svetainèje www.llt.lt.

Jonas Mardosa, Talkos Angininku kaime (Alytaus rajone). Kraštotyra, 1971, p. 175.

10 Žilvytis Bernardas Šaknys, Kalendoriniai ir darbo papročiai Lietuvoje XIX a. pabaigoje - XX a. pirmojoje puséje. Jaunimo vakarèliai. Vilnius: Diemedis, 2001.

11 Auksuolè Čepaitienè, Verpimas Lietuvoje. Liaudies kultūros likimas. Vilnius: Diemedis, 2001.

12 Morkūnas, p. 167.

13 Šaknys, Kalendoriniai ir darbo, p. 114.

14 Atbūtinès talkos, po kurių linksmybių nebūdavo, ir didžiosios, kurių nereikèjo atidirbti, būtinai būdavo su pasilinksminimu (Mardosa, Valstiečiu talkos, p. 123).

${ }^{15}$ M. Dietler \& I. Herbich, Feasts and labour mobilization: Dissecting a fundamental economic practice. Feasts: Archaeological and ethnographic perspectives on food, politics, and power, M. Dietler \& B. Hayden (Eds.), 2001, p. 240-264. Washington, DC: Smithsonian Institution Press.

${ }^{16}$ Dietler, p. 246.

17 Balys Buračas, Rugiapjūtès pabaigtuvès. Lietuvos kaimo papročiai. Vilnius, 1993, p. 64-65.

Vyšniauskaitè, Dundulienė, Mardosa, Talkos Angininku; Mardosa, Valstiečiu talkos; Mardosa, Vaiguviškiu talkos.

18 Vyšniauskaitè, p. 121.

19 Žr. Šaknys, Kalendoriniai ir darbo; Šaknys, Jaunimo neintensyvaus darbo savitumai Lietuvoje (XIX a. pabaiga - XX a. pirmoji pusè). Lituanistica 1(4), 2002, p. 42-56.

20 Šaknys, Kalendoriniai ir darbo, p. 88.

21 Šie vilniečiai paprastai vadino bendrija tiesiog bendradarbius, su kuriais tiesiogiai dirbi, su kuriais sieja darbiniai ryšiai ar su kuriais paprastai tenka dažnai bendrauti.

22 Pagal Christian Waldstrøm, Informal Networks in Organizations - A literature review, 2001, p. 33. <http://citeseerx.ist.psu.edu/viewdoc/ download?doi=10.1.1.203.3414\&rep=rep1\&type $=$ pdf $>$ [žr. 201605 10] 